\title{
Hf-Zr anomalies in clinopyroxene from spinel peridotite mantle xenoliths from Europe
}

\author{
Hilary Downes ${ }^{1}$, Caja de Vries ${ }^{1}$ and Nadine Wittig ${ }^{2}$ \\ 1.School of Earth Sciences, Birkbeck University of London, Malet Street London WC1E 7HX UK. \\ 2.Department of Earth Sciences, University of Durham Durham, DH1 3LE UK
}

Extreme depletion in $\mathrm{Hf}$ and $\mathrm{Zr}$ in clinopyroxenes from the northern part of the French Massif Central was first reported by Downes et al (2003). New LA-ICPMS analyses of clinopyroxenes from a variety of spinel peridotite mantle xenoliths from localities throughout Europe have revealed unusual and conspicuously strong negative anomalies in $\mathrm{Zr}$ and $\mathrm{Hf}$ relative to the adjacent REE Sm and Nd in mantle-normalised trace element diagrams. Most of the samples showing this anomaly are from Neogene alkaline basalts in the Massif Central and the Polish Sudetes (Figs. 1 and 2).

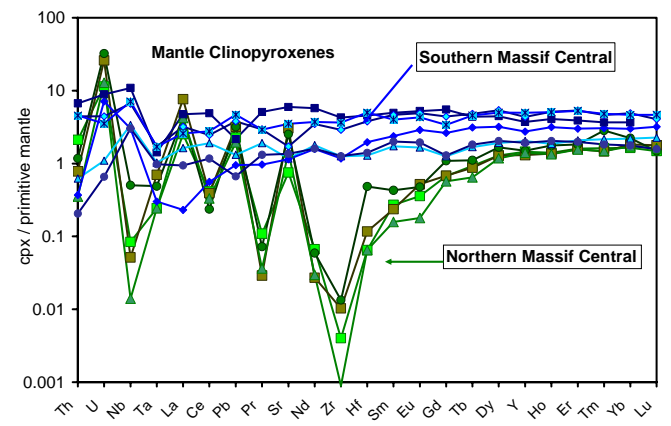

Figure 1 LA-ICPMS data for clinopyroxene in mantle xenoliths from the Northern Massif Central show extreme $\mathrm{Zr}$-Hf-depletion compared with those of the Southern Massif Central(de Vries, unpub data)

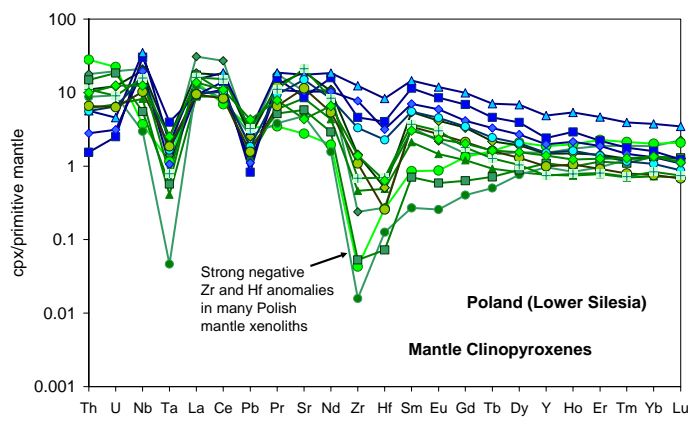

Figure 2. Data for clinopyroxenes from some mantle xenoliths from Neogene volcanics, Polish Sudete show similar $\mathrm{Zr}$-Hd depletions, but not as strong as in the Massif Central (de Vries, unpub data).

Figure 3 shows further examples of similar Zr-Hfdepleted clinopyroxenes in have been found in mantle spinel peridotite xenoliths from Mte Vulture and Sicily in southern Italy. A search of the literature has revealed that such strong $\mathrm{Zr}-\mathrm{Hf}$ anomalies (and high Lu/Hf ratios) are uncommon worldwide, although other examples are found in xenoliths from the Bearpaw Mts of Montana and Tok in Siberia (Fig. 3).

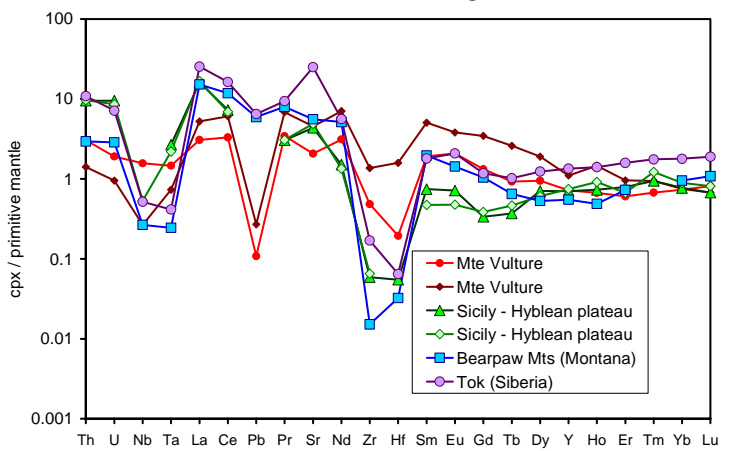

Figure 3. Examples of Zr-Hf-depleted clinopyroxenes from mantle xenoliths from Mte Vulture Italy - Downes et al., 2002; Sicily - Perinelli et al., 200; the Bearpaw Mts (Wyoming craton - Downes et al., 2004) and Tok (Siberia - Ionov et al 2006). Again, none of these examples are as strongly depleted as the Massif Central samples.

The effect of the low Hf contents (typically $<0.1 \mathrm{ppm}$ $\mathrm{Hf}$ ) is to produce extremely high $\mathrm{Lu} / \mathrm{Hf}$ ratios (typically Lu/Hf > 1) as shown in Fig. 4.

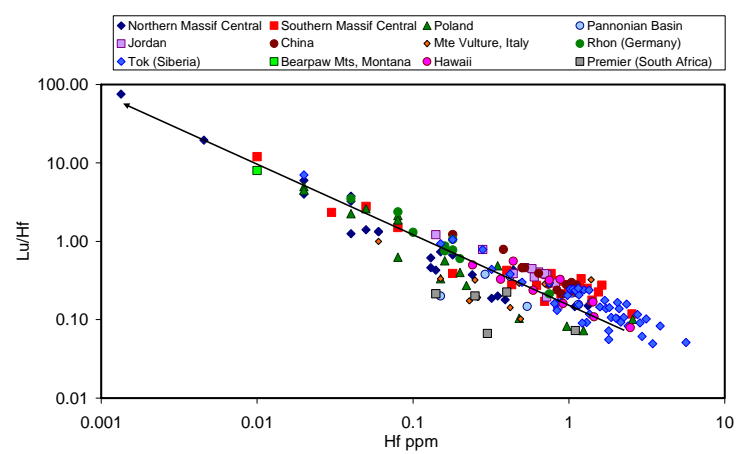

Figure 4 Mantle xenoliths from a few localities worldwide show extreme Hf-depletion and consequent high $\mathrm{Lu} / \mathrm{Hf}$ ratios similar to those of the Southern Massif Central. Note logarithmic scales on both axes. Arrow indicates increasing extent of partial melting. 
The cause of the depletion in $\mathrm{Zr}$ and $\mathrm{Hf}$ is unclear, although the Massif Central peridotites which show such depletions have generally experienced extensive partial melting (e.g. up to 30\%) in the spinel peridotite stability field.

Over geological time these high $\mathrm{Lu} / \mathrm{Hf}$ ratios will lead to extremely radiogenic $\varepsilon_{\mathrm{Hf}}$ values. In the example of the northern French Massif Central (Fig. 5), such xenoliths show ultra-radiogenic $\mathrm{Hf}$ isotope ratios $\left(\varepsilon_{\mathrm{Hf}}\right.$ values range from +40 to +2600$)$.

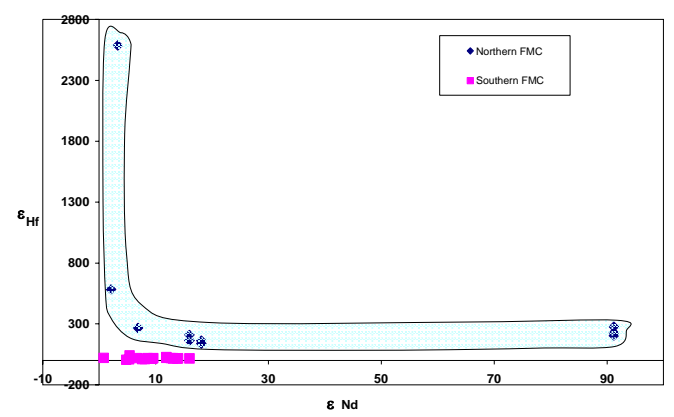

Figure 5. Hf-Nd isotope data for clinopyroxenes from mantle peridotite xenoliths from French Massif Central show differences between northern and southern regions (Wittig et al., 2007).

Thus, as shown in Fig. 6, in the northern Massif Central $\varepsilon_{H f}$ values in clinopyroxenes from mantle peridotite xenoliths are much more strongly decoupled from $\varepsilon_{\mathrm{Nd}}$ values compared with, for example, xenoliths from the oceanic lithosphere (e.g., Hawaii) or cratonic mantle. They appear to be extreme examples of mantle that is strongly radiogenic in $\mathrm{Hf}$ isotopes. Only rare xenoliths from Jordan and one from Hawaii show $\varepsilon_{\mathrm{Hf}}$ values of $>100$, although unpublished data for peridotites from Beni Bousera and Kaapvaal may have similarly extreme values (Pearson et al., 2003).

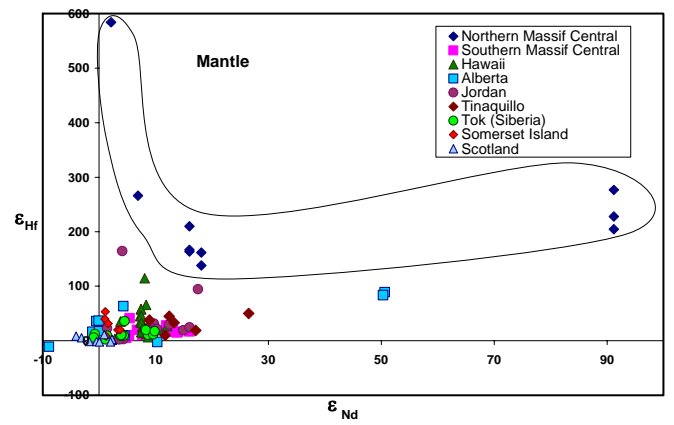

Figure 6. Hf-Nd isotope data for clinopyroxenes from mantle xenoliths from other regions worldwide (Jordan - Shaw et al., 2007; Alberta - Aulbach et al., 2004; Hawaii - Bizmis et al., 2007; Tinaquillo (whole rock) - Choi et al., 2007; Tok - Ionov et al., 2006b; Somerset Island (Canada) - Schmidberger et al., 2001, 2002; Scotland - Bonadiman et al., 2008), compared with data from Massif Central peridotite xenoliths (Wittig et al., 2007).
Clinopyroxenes with high $\mathrm{Lu} / \mathrm{Hf}$ ratios are amenable to Lu-Hf isotopic age dating (Wittig et al., 2006). Hf model ages and ${ }^{176} \mathrm{Hf} /{ }^{177} \mathrm{Hf}-{ }^{176} \mathrm{Lu} /{ }^{177} \mathrm{Hf}$ systematics of xenoliths from the northern French Massif Central (Fig. 7) indicate that depletion occurred in the mantle beneath this region in Variscan times (360Ma). This depletion may have been caused by extensive melting in a subduction-related environment (mantle wedge).

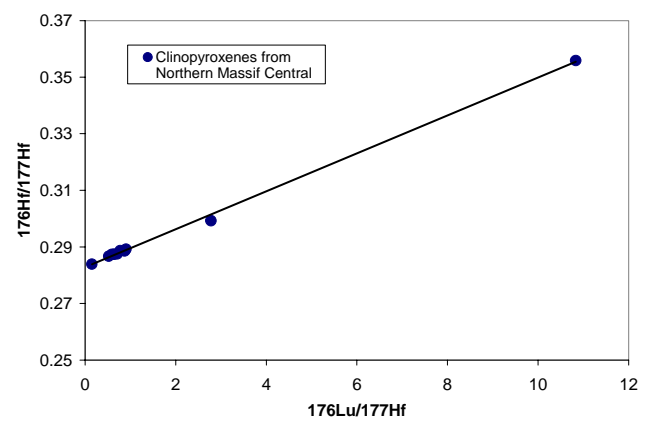

Figure 7. Lu-Hf data for clinopyroxenes from the Northern Massif Central, showing a reference isochron of $360 \mathrm{Ma}$, interpreted as age of mantle depletion (data from Wittig et al., 2006).

Since the volcanic fields of the Massif Central, Polish Sudetes and Rhon are all situated on the northern margin of the Variscan orogen, it is possible that the mantle beneath these regions experienced a similar extreme depletion event, perhaps related to suprasubduction zone processes. Tok (SE Siberia) and the Bearpaw Mts (W USA) are both in cratonic settings but are situated above regions of recent deep subduction, which may have been the cause of extreme depletion due to partial melting.

\section{References}

Aulbach S, Griffin W L, O’Reilly S Y and McCandless T E 2004. Genesis and evolution of the lithospheric mantle beneath the Buffalo Head Terrane, Alberta (Canada). Lithos 77, 413-451.

Bizmis M, Griselin M, Lassiter J C, Slaters V J M and Sen G 2007. Ancient recycled mantle lithosphere in the Hawaiian plume: Osmium-Hafnium isotopic evidence from peridotite mantle xenoliths. Earth Planet Sci. Lett. 257, 259-273.

Bonadiman C, Coltorti M, Duggen S, Paludetti L, Siena F, Thirlwall M F and Upton B G J 2008. Palaeozoic subductionrelated and kimberlite or carbonatite metasomatism in the Scottish lithospheric mantle. In: Coltorti M and Gregoire M (eds). Metasomatism in Oceanic and Continental Lithospheric Mantle. Geol. Soc. Lond. Sp. Pub. 293, 303333.

Choi S H, Mukasa S B, Andronikov A V and Marcano M C 2007. Extreme Sr-Nd-Pb-Hf isotopic compositions exhibited by the Tinaquillo peridotite massif, Northern Venezuela: implications for geodynamic setting. Contrib. Mineral. Petrol. 153, 443-463.

Downes, H., Macdonald, R., Upton, B.G.J., Cox, K.G., Bodinier, J-L., Mason, P.R.D., James, D., Hill, P.G. \& Hearn. B.C. Jr. (2004). Ultramafic Xenoliths from the Bearpaw Mountains, Montana, USA: Evidence for Multiple 
Metasomatic Events in the Lithospheric Mantle beneath the Wyoming Craton. Journal of Petrology 45, 1631-1662.

Downes H, Kostoula T, Jones A, Beard A, Thirlwall M and Bodinier J-L 2002. Geochemistry and Sr-Nd isotopic compositions of mantle xenoliths from the Monte Vulture carbonatite-melilitite volcano, central southern Italy. Contrib. Mineral. Petrol. 144, 78-92.

Downes H, Reichow M K, Mason P R D, Beard A D and Thirlwall M F 2003. Mantle domains in the lithosphere beneath the French Massif Central: trace element and isotopic evidence from mantle clinopyroxenes. Chemical Geology 200, 71-87.

Ionov D A, Chazot G, Chauvel C, Merlet C, Bodinier J L 2006a. Trace element distribution in peridotite xenoliths from Tok, SE Siberian craton: A record of pervasice multi-stage metasomatism in the shallow refractory mantle. Geochim. Cosmochim. Acta 70, 1231-1260.

Ionov D A, Shirey S B, Weiss D and Brugmann G 2006b. Os-Hf-Sr-Nd isotope and PGE systematics of spinel peridotite xenoliths from Tok, SE Siberian craton: Effects of pervasive metasomatism in the shallow refractory mantle. Earth Planet. Sci. Lett. 241, 47-64.

Pearson D G, Canil D and Shirey S B 2003. Mantle samples included in volcanic rocks: Xenoliths and diamonds. Treatise on Geochemistry vol 2, Section 2.05.

Perinelli C, Sapienza G T, Armienti P and Morten L 2008. Metasomatism of the upper mantle beneath the Hyblean
Plateau (Sicily): evidence from pyroxenes and glass in peridotite xenoliths. In: Coltorti $\mathrm{M}$ and Gregoire $\mathrm{M}$ (eds). Metasomatism in Oceanic and Continental Lithospheric Mantle. Geol. Soc. Lond. Sp. Pub. 293, 197-221.

Schmidberger S S, Simonetti A and Francis D 2001. Sr-Nd$\mathrm{Pb}$ isotope systematics of mantle xenoliths from Somerset Island kimberlites: Evidence for lithosphere stratification beneath Arctic Canada. Geochim. Cosmochim. Acta. 65, 4243-4255.

Schmidberger S S, Simonetti A, Francis D and Gariepy C 2002. Probing Archean lithosphere using the Lu-Hf isotope systematics of peridotite xenoliths from Somerset ISl;and kimberlites, Canada. Earth Planet. Sci. Lett. 197, 245-259.

Shaw J E, Baker J A, Kent A J R, Ibrahim K M and Menzies M A, 2007. The geochemistry of the Arabian lithospheric mantle - a source for intraplate volcanism? J. Petrol. 48, 1495-1512.

Wittig N, Baker J A, Downes H 2006. Dating the mantle roots of young continental crust. Geology 34, 237-240.

Wittig N, Baker J A, Downes H 2007. U-Th-Pb and Lu-Hf isotopic constraints on the evolution of sub-continental lithospheric mantle, French Massif Central. Geochim. Cosmochim. Acta, 71, 1290-1311. 